\title{
Induction of Apoptosis by Disturbing Mitochondrial-Membrane Potential and Cleaving PARP in Jurkat $T$ Cells through Treatment with Acetoxyscirpenol Mycotoxins
}

\author{
Dong Hee LeE, ${ }^{a}$ Taesun PARK, ${ }^{b}$ and Ha Won KIM*,a \\ ${ }^{a}$ Department of Life Sciences, University of Seoul; Seoul 130-743 Korea: and ${ }^{b}$ Department of Food and Nutrition, Yonsei \\ University; Seoul 120-749, Korea. Received October 28, 2005; accepted January 10, 2006
}

\begin{abstract}
Paecilomyces tenuipes is a famous Chinese medicinal entomopathogenic fungus that grows within the larvae of silkworms. $4 \beta$-acetoxyscirpendiol (4-MAS), a cytotoxic compound belonging to the scirpenol subfamily of trichothecene mycotoxin, was isolated from Paecilomyces tenuipes. To further elucidate the cytotoxic mechanism of 4-MAS, evidences of its induction of apoptosis, together with the structurally related acetoxyscirpenol moiety mycotoxins (ASMs) such as, 15-acetoxyscirpenol (15-MAS), 4,15-diacetoxyscirpenol (4,15-DAS), and 3 $\alpha$-acetyldiacetoxyscirpenol (TAS), in the human Jurkat $\mathrm{T}$ cell line were reported herein. In the MTT reduction and timecourse cytotoxicity assays for monitoring cell viability, all the four ASMs that were tested exhibited cytotoxicity; single acetoxylation at $\mathrm{C}-4$ of the scirpenol family resulted in relatively weak cytotoxicity, while acetoxylation at $\mathrm{C}-15$ resulted in strong cytotoxicity regardless of the other acetoxylations at the C-3 and/or C-4 positions. Phosphatidylserine externalization was induced by all the ASMs that were treated at an early phase in a time-dependent manner, showing a typical apoptotic phenomenon, not a necrotic one. The ASMs also reduced the mitochondria's inner-membrane potential $(\Delta \Psi \mathrm{m})$ through flow cytometry analysis after staining these with $\mathrm{DiOC}_{6}$, a mitochondria-specific and voltage-dependent dye. Acetoxylation of ASM at C-15 increased $\Delta \Psi$ m disruption, but that at $\mathrm{C}-3$ reduced the $\Delta \Psi \mathrm{m}$. The ASMs that were tested also cleaved $113 \mathrm{kDa}$ PARP to an $89-\mathrm{kDa}$ fragment through Western blot assay, suggesting the activation of caspase-3 and/or caspase-7 in the Jurkat T cell. DNA fragmentation was also observed to have been increased in a time-dependent manner by the ASMs that were tested in Jurkat $T$ cells, resulting in the DNA fragmentation intensity order of 4,15-DAS $>15-M A S>$ TAS $>4$ MAS. These data indicate that the Jurkat $T$ cells that were treated with ASMs underwent typical cascades of apoptotic cell death.
\end{abstract}

Key words acetoxyscirpenol; Paecilomyces tenuipes; apoptosis; mitochondrial membrane potential; caspase; DNA fragmentation

Apoptosis is a coordinated cell death, characterized by morphological and biochemical changes such as cell shrinkage, membrane blebbing, phosphatidylserine (PS) externalization, the potential loss of the mitochondrial membrane, poly (ADP-ribose) polymerase (PARP) cleavage, chromatin condensation and genomic DNA fragmentation. External stimulation may induce apoptosis as well as necrosis. These two types of cell death can be distinguished from each other by using various methods, such as the flow cytometric assay using annexin $\mathrm{V}$ and propidium iodide (PI). ${ }^{1)}$ Annexin $\mathrm{V}$ is a calcium-dependent phospholipid-binding protein that possesses a strong affinity with PS, which is externalized onto the cell surface in the early stages of apoptotic cell death. ${ }^{2)}$ Apoptosis constitutes a crucial process for eliminating cancer cells; antitumor agents with different modes of action have been reported to trigger apoptosis in chemosensitive cells. ${ }^{3)}$

In many systems, apoptosis is associated with the loss of mitochondrial inner membrane potential $(\Delta \Psi \mathrm{m})$, which may be regarded as a limiting factor in the apoptotic pathway. ${ }^{4)}$ This loss was reported to be associated with the induction of mitochondrial permeability transition and/or channel-forming by the Bax. ${ }^{5)}$ Another characteristic of apoptosis is the cleavage of PARP by activated caspases. Activated caspase-3 and/or caspase-7 cleaves PARP to an $89-\mathrm{kDa}$ signature fragment, in a DEVD $\downarrow G$ sequence separating the amino-terminal DNA-binding domain from the carboxyl-terminal catalytic domain of the enzyme. PARP is a nuclear DNA-binding protein of $113 \mathrm{kDa}$ that is constitutively expressed in eukaryotes and that comprises up to $1 \%$ of the total nuclear proteins. ${ }^{6}$
At lower levels of DNA damage, the PARP inhibits the proapoptotic $\mathrm{Ca}^{2+} / \mathrm{Mg}^{2+}$ endonuclease, and thus protects cells against apoptosis. ${ }^{7)}$ DNA fragmentation associated with apoptosis is induced by the DNA fragmentation factor (DFF), which is activated by caspases, mainly caspase-3. DFF is composed of two protein subunits, a 40-kDa caspaseactivated nuclease (DFF40/CAD), and its $45-\mathrm{kDa}$ inhibitor (DFF45/ICAD). The cleavage of DFF45/ICAD by caspase-3 releases DFF40/CAD from its inhibitor, leading to the induction of nuclease activity, nuclear condensation, and DNA fragmentation in vitro. ${ }^{8)}$ TUNEL (TdT-mediated dUTP nickend labeling) assay usually involves the terminal nucleotide transferase-mediated polymerization of labelled dUDP, in a template-independent manner, at the site of DNA breaks at $3^{\prime}$-OH. ${ }^{1)}$

Mycotoxins of scirpenol belong to the trichothecene family, which is produced mainly by the fungal species of the genus Fusarium. The chemical structure of scirpenol has three hydroxyl groups which can be acetoxylated during the biosynthesis in Fusarium. Further metabolized, fully acetoxylated scirpenol becomes T-2 toxin, which is known as a highly toxic mycotoxin. ${ }^{10,11)}$ Acetoxylated scirpenol also has very high toxicities in animas ${ }^{12)}$ and humans. ${ }^{13)}$ The cytotoxic compound of $4 \beta$-acetoxyscirpendiol (4-MAS) is a C-4 monoacetoxylated form of scirpenol, a subfamily of trichothecene mycotoxins. Trichothecenes were reported to inhibit protein synthesis by binding to the ribosomal peptidyl transferase site. ${ }^{14)}$ 4-MAS isolated from Isaria japonica induced apoptosis though caspase-3 activation and DNA frag- 
(A)

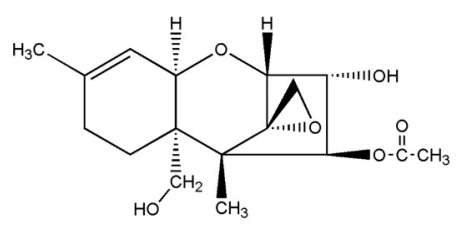

(C)

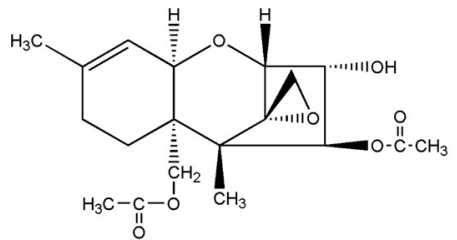

(B)

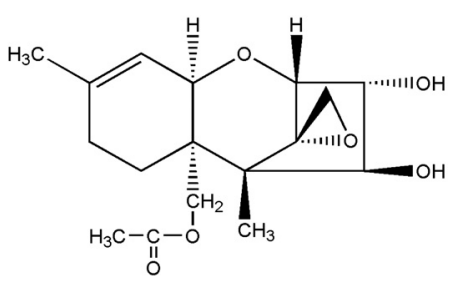

(D)

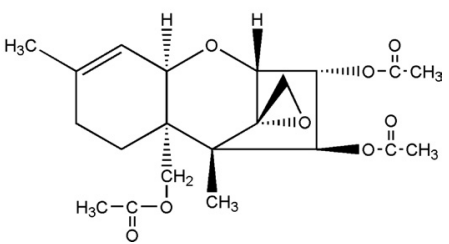

Fig. 1. Chemical Structures of ASM Family Used in This Study

(A) 4 $\beta$-Acetoxyscirpendiol (4-MAS), (B) 15-acetoxyscirpenol (15-MAS), (C) 4,15-diacetoxyscirpenol (4,15-DAS), (D) $3 \alpha$-acetyldiacetoxyscirpenol (TAS).

mentation. ${ }^{15)}$ Recently, we had reported the isolation of 4MAS from Paecilomyces tenuipe, ${ }^{16)}$ which is an edible entomopathogenic fungus that infects an insect's body during summer, remains dormant throughout winter, and then forms a plant-like fruiting body during the following spring or summer. ${ }^{17)}$ In continuation of our efforts revealing action mechanisms of 4-MAS, the modulation of the cell-cycle-related gene expression in the MCF-7 cell line, ${ }^{18)}$ the inhibition of GLUT-1 in Xenopus laevis, ${ }^{19)}$ the inhibition of the sodium glucose co-transporter, ${ }^{20)}$ and cell-cycle arrest ${ }^{21)}$ had been reported.

Derivatives of scirpenol do not precisely follow the pattern that was reported earlier for the T-2 toxin subfamily of trichothecene, in which a decrease in the number of acetyl groups is accompanied by a decrease in toxicity. ${ }^{22)}$ In connection with apoptosis, comparative studies on the number and positions of acetoxyl groups in scirpenol moiety are not well documented. In this study, evidences of the induction of apoptosis and a structure-activity relationship by acetoxyscirpenol mycotoxins (ASMs, Fig. 1) were reported.

\section{MATERIALS AND METHODS}

Reagents Staurosporine, camptothecin, 15-acetoxyscirpenol (15-MAS), 4,15-diacetoxyscirpenol (4,15-DAS), $3 \alpha$ acetyldiacetoxyscirpenol (TAS), 3-[4,5-dimethylthiazol-2-yl] 2,5-diphenyl tetrazolium bromide (MTT) reagent, and 3,3'dihexyloxacarbocyanine iodide $\left(\mathrm{DiOC}_{6}\right)$ were purchased from Sigma-Aldrich Co. (St. Louis, U.S.A.). The compound of 4-MAS was isolated from the methanol extract of Paecilomyces tenuipes. ${ }^{16)}$ The fluorescein isothiocyanate-labeled annexin V (Annexin-V-FITC) kit, the Apo-Direct ${ }^{\mathrm{TM}}$ (DNA fragmentation detection) kit, $N$-acetyl-Asp-Glu-Val-AspCHO (Ac-DEVD-CHO, a caspase 3 inhibitor), Z-Val-AlaAsp-(O-methyl)- $\mathrm{CH}_{2} \mathrm{~F}$ (Z-VAD-FMK, a pan-caspase inhibitor) and the mouse anti-human PARP monoclonal antibody were purchased from BD Biosciences Pharmingen (San Diego, U.S.A.). The HRP-conjugated goat anti-mouse IgG antibody was obtained from Southern Biotechnology Associates, Inc. (Birmingham, U.S.A.).
Cell Viability and MTT Assay Human T-lymphoid Jurkat (ATCC, Rockville, U.S.A.) cells were maintained in an RPMI-1640 medium (Life Technologies, Inc., Eggenstein, Germany) supplemented with a 10\%-heat-inactivated fetalbovine serum (JRH Biosciences Co., Lenexa, U.S.A.) as well as penicillin (100 units $/ \mathrm{ml})$ and streptomycin $(100 \mu \mathrm{g} / \mathrm{ml})$ (Life Technologies, Inc.), and were incubated at $37^{\circ} \mathrm{C}$ in $5 \%$ $\mathrm{CO}_{2}$. The ASMs were dissolved in DMSO and were further diluted with an RPMI-1640 medium. The maximum content of DMSO in the culture medium was below $1 \%$. The cells were treated with ASMs of varied concentrations $(0,10,25$, $50,100,250 \mathrm{ng} / \mathrm{ml}$ ) for $72 \mathrm{~h}$. For the time-course viability assay, cells were incubated with $25 \mathrm{ng} / \mathrm{ml}$ of $15-\mathrm{MAS}, 4,15$ DAS or TAS, or $50 \mathrm{ng} / \mathrm{ml}$ of $4-\mathrm{MAS}$ for up to $72 \mathrm{~h}$. Staurosporine was used as a positive control. To measure cell viability by MTT assay, Jurkat T cells $\left(1.0 \times 10^{5}\right.$ cells per well $)$ were cultured in 96-well culture plates in the presence or absence of ASMs. The cytotoxic effects of these compounds were observed under a microscope everyday. After 3-d culture, cell viability was measured using the MTT colorimetric method. $10 \mu \mathrm{g}$ of $5 \mathrm{mg} / \mathrm{ml} \mathrm{MTT} \mathrm{was} \mathrm{then} \mathrm{added} \mathrm{to} \mathrm{each} \mathrm{well.}$ After 4-h incubation, $100 \mu \mathrm{g}$ of $0.04-\mathrm{N} \mathrm{HCl}$-isopropanol was added for the extraction of the dye. When all the crystals had been dissolved through the repeated pipetting of the medium, the optical density was measured with the use of a microplate reader (BIO-RAD, U.S.A.) at the wavelength of $540 \mathrm{~nm}$.

Annexin V Assay Cells $\left(2 \times 10^{6}\right)$ that had been collected and washed twice with phosphate buffered saline (PBS) were cultured with ASM for 3 and $6 \mathrm{~h}$ in a 6 -well plate. The cells were then resuspended in an annexin-V-binding buffer containing $10 \mathrm{~mm}$ Hepes- $\mathrm{NaOH}, \mathrm{pH} 7.4,140 \mathrm{~mm} \mathrm{NaCl}$, and $2.5 \mathrm{~mm} \mathrm{CaCl}_{2}$ at a final cell concentration of $1 \times 10^{6}$ cells $/ \mathrm{ml}$. The $100 \mu \mathrm{g}$-cell solution was then incubated with $5 \mu \mathrm{g}$ of FITC-conjugated annexin V and $2 \mu \mathrm{g}$ of $50 \mu \mathrm{g} / \mathrm{ml}$ PI at room temperature, in the dark, for $15 \mathrm{~min}$. After adding a $400 \mu \mathrm{l}$ annexin-V-binding buffer, the cells were processed through flow cytometry. Data acquisition and analysis were then performed in a FACSCalibur ${ }^{\mathrm{TM}}$ using the CellQuest software (Becton Dickinson Co., USA). ${ }^{23)}$ PI was added so that apoptotic and necrotic cells could be distinguished from each 
other. The percentage of apoptotic cells was determined based on the percentage of cells that had bound to annexin VFITC but were negative for PI uptake. ${ }^{24)}$ A known inducer of apoptosis, staurosporine was used in the assay system.

Measurement of Mitochondrial-Membrane Potential During apoptosis, mitochondrial-membrane potential is lost. Cells $\left(2 \times 10^{6}\right)$ were treated with ASM for 6 and $12 \mathrm{~h}$ in a 6well plate. The changes in the $\Delta \Psi \mathrm{m}$ were determined by incubating PBS-washed $1 \times 10^{6}$ cells in $40 \mathrm{nM} \mathrm{DiOC}_{6}$ and $1 \mu \mathrm{g} / \mathrm{ml}$ PI for $15 \mathrm{~min}$ at $37^{\circ} \mathrm{C}$. After washing, the cells were resuspended in $1 \mathrm{ml}$ PBS ( $\mathrm{pH} 7.4)$ and were then analyzed using FACSCalibur ${ }^{\mathrm{TM}}$ flow cytometry. ${ }^{4,25)}$ For the $\mathrm{DiOC}_{6}{ }^{-}$ stained samples, PI-negative cells were excluded. At least 5000 cells were analyzed for each sample.

PARP Cleavage and Caspase Involvement Cells $\left(2 \times 10^{6}\right)$ were cultured with ASMs for 6 and $18 \mathrm{~h}$ in a 6 -well plate for PARP cleavage assay. $1 \times 10^{6}$ cells were then harvested and washed twice with cold PBS ( $\mathrm{pH} 7.4$ ), and were lysed for $30 \mathrm{~min}$ in an ice-cold lysis buffer containing $50 \mathrm{~mm}$ Tris- $\mathrm{Cl}, \mathrm{pH} 8.0,150 \mathrm{~mm} \mathrm{NaCl}, 0.02 \%$ sodium azide, $0.5 \%$ sodium deoxycholate, $0.1 \%$ SDS, $1 \%$ NP-40, $2 \mu \mathrm{g} / \mathrm{ml}$ pepstatin A, $2 \mu \mathrm{g}$ leupeptin, $104.4 \mu \mathrm{g} / \mathrm{ml} \mathrm{PMSF}$, and $2 \mu \mathrm{g} / \mathrm{ml}$ aprotinin, and were made to undergo high-speed centrifugation at $12000 \times \mathbf{g}$. The protein concentration was assayed using Bradford reagent (Sigma Chem. Co., U.S.A.). 20$30 \mu \mathrm{g}$ proteins/lane were separated on an $8 \%$ SDS-PAGE gel and were electroblotted onto nitrocellulose (Schleicher \& Schnell Inc., Germany). After being blocked for $2 \mathrm{~h}$ in a TBS-T buffer (10 mm Tris-Cl, pH 7.6, $150 \mathrm{~mm} \mathrm{NaCl),} \mathrm{it} \mathrm{was}$ supplemented with 5\% non-fat dry milk and $0.1 \%$ Tween 20 (Sigma Chem. Co., U.S.A.). The immunodetection of PARP protein was performed using a mouse anti-PARP monoclonal antibody (1:500) and a goat anti-mouse $\mathrm{IgG}$ antibody (1:5000), followed by ECL (Amersham Pharmacia Biotech, U.S.A.) detection. ${ }^{26)}$ The full-length $(113 \mathrm{kDa})$ PARP and its proteolytic fragment $(89 \mathrm{kDa})$ were quantified through $\mathrm{KDS}_{1} \mathrm{~d}^{\mathrm{TM}}$ image analysis. To analyze the involvement of caspases in apoptosis induced by ASMs, caspase inhibitors were incorporated in PARP cleavage analyses. Jurkat T cells were pre-incubated for $3 \mathrm{~h}$ in the absence or presence of the pancaspase inhibitor, Z-VAD-FMK $(10 \mu \mathrm{M})$ or the caspase- 3 inhibitor, Ac-DEVD-CHO $(10 \mu \mathrm{M})$. The cells were then treated with ASMs for $18 \mathrm{~h}$. Each cell lysate was subjected to an immunoblot analysis with antibodies to PARP.

Detection of DNA Fragmentation Cells $\left(2 \times 10^{6}\right)$ were cultured with ASMs for 6 and $18 \mathrm{~h}$ in a 6-well plate. They were then washed and resuspended in $1 \%(\mathrm{w} / \mathrm{v})$ paraformaldehyde in PBS $(\mathrm{pH} 7.4)$ at a concentration of $2 \times 10^{6}$ cells $/ \mathrm{ml}$ and were placed on ice for $1 \mathrm{~h}$. The cells were then centrifuged for $5 \mathrm{~min}$ at $300 \times \boldsymbol{g}$, and the pellet was washed twice. The cells were resuspended in the residual PBS in a tube by gently vortexing them, supplemented with $1 \mathrm{ml}$ of cold $70 \%(\mathrm{v} / \mathrm{v})$ ethanol, and were incubated at $-20{ }^{\circ} \mathrm{C}$ overnight. To remove ethanol, the cells were washed twice with a wash buffer, and were added to a $50 \mu$ l staining solution containing a reaction buffer, a terminal deoxynucleotide transferase (TdT) enzyme and FITC-dUTP. After being incubated for $60 \mathrm{~min}$ at $37^{\circ} \mathrm{C}$, the cells were washed twice with a rinse buffer, were resuspended in a $0.5 \mathrm{ml}$ $\mathrm{PI} / \mathrm{RNase}$ staining buffer, and were incubated for $30 \mathrm{~min}$ in the dark at room temperature. Finally, the cells in the
(A)

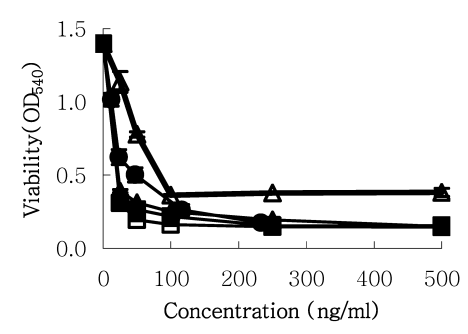

(B)

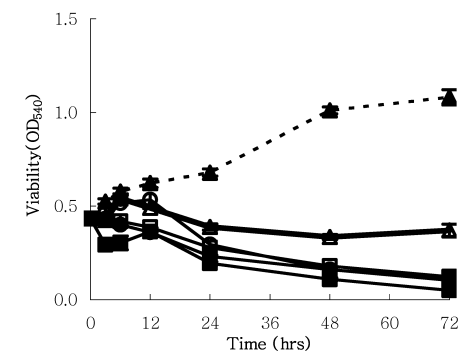

Fig. 2. Cell Viability in Response to Acetoxylated Scirpenol Mycotoxins in Jurkat T Cells

(A) Jurkat $\mathrm{T}$ cells were incubated with varied concentrations of staurosporine $(\mathbf{O})$, 4$\operatorname{MAS}(\triangle)$, 15-MAS $(\boldsymbol{\square}), 4,15$-DAS $(\square)$ or TAS $(\boldsymbol{\Delta})$ for $72 \mathrm{~h}$ at $37^{\circ} \mathrm{C}$ in a humidified $5 \% \mathrm{CO}_{2}$ environment. The measurement of cell viability was performed through the MTT reduction assay. (B) The time-course effects of control ( $\boldsymbol{A}$, PBS), staurosporine $(\boldsymbol{\square}, 93 \mathrm{ng} / \mathrm{ml}), 4-M A S(\triangle, 50 \mathrm{ng} / \mathrm{ml}), 15-\mathrm{MAS}(\square, 25 \mathrm{ng} / \mathrm{ml}), 4,15$-DAS $(\bullet, 25 \mathrm{ng} / \mathrm{ml})$ and TAS $(O, 25 \mathrm{ng} / \mathrm{ml})$ were measured by using the MTT reduction assay. Values are means \pm S.D. of 3 independent determinations.

$\mathrm{PI} / \mathrm{RNase}$ solution were analyzed with the use of the flow cytometer. ${ }^{1,27)}$

Statistics All statistical analyses were performed using Sigma-Stat 3.0 (Statsoft, U.S.A.). Data were analyzed by one-way ANOVA (analysis of variance) followed by HolmSidak method. $p$-values $<0.05$ were considered significant.

\section{RESULTS}

Cytotoxicity of ASMs in Jurkat T Cells To determine the comparative cytotoxicities of the acetoxyl derivatives of scirpenol mycotoxins, human Jurkat T cells were treated with various ASMs of different concentrations and at varied time intervals. All the ASMs that were tested strongly inhibited Jurkat $T$ cell growth in a dose-dependent manner (Fig. 2A). Among them, 4-MAS exhibited the least cytotoxicity based on cell viability. According to the time-course study of cytotoxicity, most of the ASMs began to exert cytotoxicity in the Jurkat $\mathrm{T}$ cells after 12-h incubation. 4-MAS exhibited less cytotoxicity at a higher concentration $(50 \mathrm{ng} / \mathrm{ml})$ compared with the other members of the acetoxylscirpehol family (15MAS, 4,15-DAS and TAS) that were used at a lower concentration $(25 \mathrm{ng} / \mathrm{ml})$ (Fig. 2B). The $50 \%$ inhibitory concentration $\left(\mathrm{IC}_{50}\right)$ values of 4-MAS, 15-MAS, 4,15-DAS and TAS were $59.5,16.1,16.1$ and $17.3 \mathrm{ng} / \mathrm{ml}$, respectively (Table 1). As for 4-MAS cytotoxicity, the Jurkat $\mathrm{T}$ cell was much more sensitive than the other cell lines, such as the mouse sarcoma-180 or human SNU cancer cell lines. ${ }^{16)}$ Based on these results, it can be concluded that single acetoxylation at the $\mathrm{C}$ 4 position of the scirpenol family confers relatively weak cytotoxicity. On the other hand, acetoxylation at the C-15 position resulted in stronger cytotoxicity regardless of the pres- 
Table 1. Cytotoxic Effects of ASMs on Jurkat T Cells

\begin{tabular}{lc}
\hline \hline Compounds $^{a)}$ & $\left.\mathrm{IC}_{50}{ }^{b}\right)(\mathrm{ng} / \mathrm{ml})$ \\
\hline Staurosporine & 20.9 \\
4-MAS & 59.5 \\
15-MAS & 16.1 \\
4,15-DAS & 16.1 \\
TAS & 17.3
\end{tabular}

a) Staurosporine was used as a positive control. 4-MAS, $4 \beta$-acetoxyscirpendiol; 15 MAS, 15-acetoxyscirpenol; 4,15-DAS, 4,15-diacetoxyscirpenol and TAS, $3 \alpha$-acetyldiacetoxyscirpenol. b) The $50 \%$ inhibitory concentration $\left(\mathrm{IC}_{50}\right)$ was measured by the MTT assay after $72 \mathrm{~h}$ incubation.

Table 2. Redistribution of Phosphatidylserine to the Outer Surface of Jurkat T Cells Induced by ASMs

\begin{tabular}{lcc}
\hline \hline \multirow{2}{*}{ Compounds } & \multicolumn{2}{c}{ Externalization of PS (\%) } \\
\cline { 2 - 3 } & $3 \mathrm{~h}$ & $6 \mathrm{~h}$ \\
\hline Control & 4.7 & 3.3 \\
Staurosporine $(100 \mathrm{ng} / \mathrm{ml})$ & 23.2 & 28.3 \\
4-MAS (50 ng/ml) & 9.3 & 11.7 \\
15-MAS (50 ng/ml) & 17.9 & 32.6 \\
4,15-DAS (50 ng/ml) & 23.8 & 32.0 \\
TAS (50 $\mathrm{ng} / \mathrm{ml})$ & 18.1 & 34.0
\end{tabular}

ASM treated cells were stained with a mixture solution of FITC-annexin V and propidium iodide for $15 \mathrm{~min}$ in the dark at room temperature. After washing, cells were analyzed in a FACSCalibur ${ }^{\mathrm{TM}}$ using the CellQuest software.

ence of other acetoxylations at the C-3 and/or C-4 position.

ASMs Trigger Apoptosis, Not Necrosis To determine the cytotoxic mechanism of the scirpenol family, the PS externalization was analyzed to distinguish apoptosis from necrosis by incubating the cells for 3 and $6 \mathrm{~h}$ with the ASMs. During the early phase of the apoptosis, the PS of the inner leaflet of the plasma membrane moved outwardly. By incubating the cells with FITC-annexin V along with PI reagent, annexin $\mathrm{V}$ bound to the cell population with externalized PS, which was measured with the use of the flow cytometer. As shown in Table 2, PS externalization was induced by all the ASMs that were tested in a time-dependent manner. The populations of externalized PS-positive and PI-negative cells were $11.7,32.6,32.0$ and $34.0 \%$ for those treated with $50 \mathrm{ng} / \mathrm{ml}$ of 4-MAS, 15-MAS, 4,15-DAS and TAS, respectively for $6 \mathrm{~h}$. The ASMs that were tested, with the exception of 4-MAS, resulted in higher PS-positive cell populations at a lower concentration $(50 \mathrm{ng} / \mathrm{ml})$ compared with staurosporine that was used at a higher concentration $(100 \mathrm{ng} / \mathrm{ml})$. The fully acetoxylated TAS exhibited the most significant PS-externalization after a 6-h-incubation. This result is a compelling evidence that ASMs trigger apoptosis, not necrosis.

ASMs Reduce the Mitochondrial-Membrane Potential In many systems, apoptosis is associated with the loss of $\Delta \Psi \mathrm{m}$, which may be regarded as a limiting factor in the apoptotic pathway. ${ }^{4)}$ To observe the change in $\Delta \Psi \mathrm{m}$, Jurkat $\mathrm{T}$ cells were exposed to ASMs and $\mathrm{DiOC}_{6}$, a mitochondria-specific and voltage-dependent dye. The treatment of the Jurkat $\mathrm{T}$ cells with ASM for $12 \mathrm{~h}$ significantly reduced their $\Delta \Psi \mathrm{m}$. Among these toxins, 4,15-DAS induced the most significant loss of $\Delta \Psi \mathrm{m}(45.4 \%$ of the cell population lost their mitochondrial potential) (Fig. 3). The order of the ASMs with a higher activity of disrupting the $\Delta \Psi \mathrm{m}$ of Jurkat $\mathrm{T}$ cells was
(A)

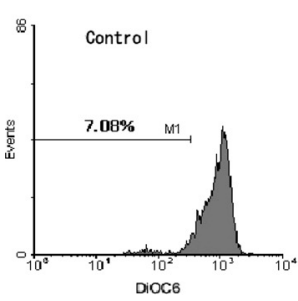

(C)

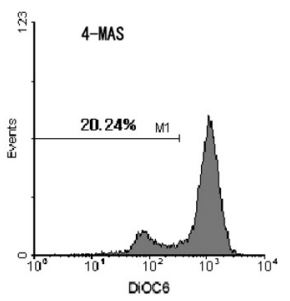

(E)

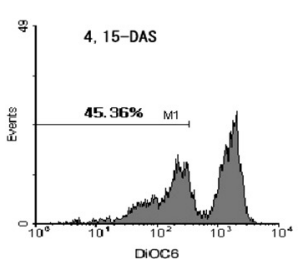

(B)

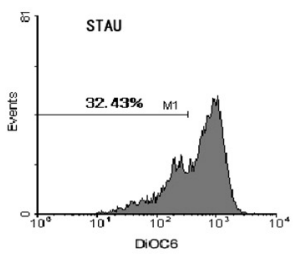

(D)

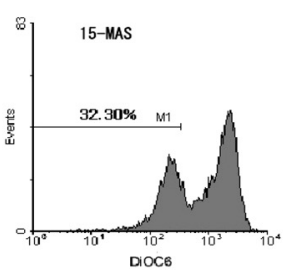

(F)

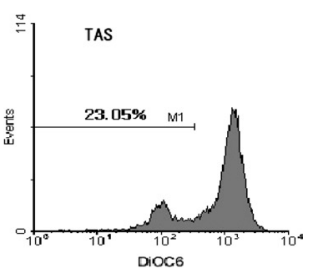

Fig. 3. Loss of the Mitochondrial Inner Membrane Potential $(\Delta \Psi \mathrm{m})$ Induced by ASMs

Jurkat T cells were treated with $100 \mathrm{ng} / \mathrm{ml}$ staurosporine (B), $100 \mathrm{ng} / \mathrm{ml}$ 4-MAS (C), $50 \mathrm{ng} / \mathrm{ml} 15-\mathrm{MAS}$ (D), $50 \mathrm{ng} / \mathrm{ml} \mathrm{4,15-DAS}$ (E), and $50 \mathrm{ng} / \mathrm{ml}$ TAS (F) for $12 \mathrm{~h}$. Cells were stained with $40 \mathrm{~nm} \mathrm{DiOC}$ and $1 \mu \mathrm{g} / \mathrm{ml}$ propidium iodide, and $\Delta \Psi \mathrm{m}$ was measured by flow cytometry. Propidium iodide was used as a counterstain.

4,15-DAS $>15-\mathrm{MAS}>\mathrm{TAS}>4$-MAS. These results suggest that acetoxylation at C-15 of scirpenol increases the latter's activity of disrupting mitochondrial potential, while acetoxylation at $\mathrm{C}-3$ reduces its disrupting activity.

PARP Is Cleaved to an 89-kDa Fragment in Response to ASMs As ASM-induced apoptosis was observed in the previous studies, the involvement of caspase in this ASM-induced apoptosis system was investigated in this study. Whole cell lysates were generated for immunoblotting with antibodies against the caspase substrates, PARP. During the execution phase of apoptosis, caspases were activated and cleaved to a cellular PARP. The cleavage of a $113 \mathrm{kDa}$ PARP to an 89-kDa fragment occurs at a DEVD $\downarrow$ G sequence, separating it into an amino-terminal DNA-binding domain and a carboxyl-terminal catalytic domain of the enzyme, or activating caspase-3 and/or caspase-7. As shown in Fig. 4, all the ASMs that were tested induced the cleavage of a $113 \mathrm{kDa}$ PARP to an $89 \mathrm{kDa}$ fragment. The control cells did not show the cleavage of the $113 \mathrm{kDa}$ PARP, while the cells treated with staurosporine, used as a positive control, resulted in a $34 \%$ cleavage of PARP after 6 -h incubation. Among the ASMs, 4,15-DAS led to a 53\% cleavage of PARP showing the most effective activity within the 6-h treatment. The 


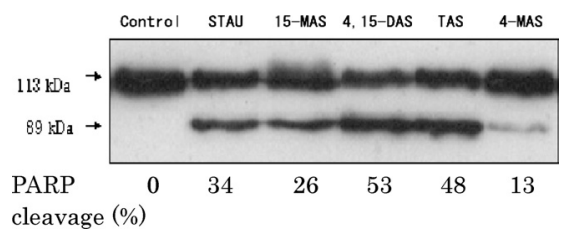

Fig. 4. PARP Cleavage Induced by ASMs

Lysates of the Jurkat T cell treated with ASM for $6 \mathrm{~h}$ were subjected to an immunoblot analysis using the antibody to PARP. The positions of a full-length $(113 \mathrm{kDa})$ PARP and of a proteolytic fragment $(89 \mathrm{kDa})$ are indicated. Quantifications of PARP cleavage were performed through $\mathrm{KDS} 1 \mathrm{~d}^{\mathrm{TM}}$ image analysis. The ratio of cleaved PARP was $0,34,26,53,48$ and $13 \%$ in cells treated with PBS, staurosporine $(100 \mathrm{ng} / \mathrm{ml}), 15$ MAS $(50 \mathrm{ng} / \mathrm{ml}), 4,15-D A S(50 \mathrm{ng} / \mathrm{ml})$, TAS $(50 \mathrm{ng} / \mathrm{ml})$ and 4-MAS $(100 \mathrm{ng} / \mathrm{ml})$, respectively, for $6 \mathrm{~h}$
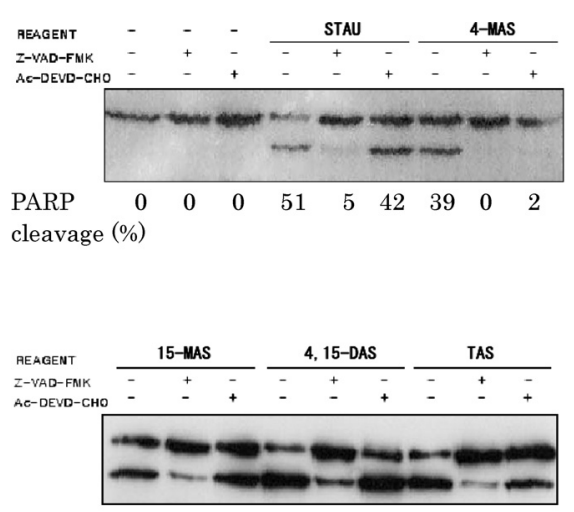

$\begin{array}{llllllllll}\text { PARP } & 51 & 14 & 44 & 75 & 23 & 69 & 66 & 13 & 35\end{array}$ cleavage (\%)

Fig. 5. Involvement of Caspases in ASM-Induced Apoptosis

Jurkat T cells were pre-incubated in the absence or presence of $10 \mu \mathrm{M}$ Z-VAD-FMK, pan-caspase inhibitor or $10 \mu \mathrm{M}$ Ac-DEVD-CHO, caspase- 3 inhibitor for $3 \mathrm{~h}$. The cells were then treated with $100 \mathrm{ng} / \mathrm{ml}$ staurosporine, $100 \mathrm{ng} / \mathrm{ml} 4-\mathrm{MAS}, 50 \mathrm{ng} / \mathrm{ml} 15-\mathrm{MAS}$, $50 \mathrm{ng} / \mathrm{ml} \mathrm{4,15-DAS}$ or $50 \mathrm{ng} / \mathrm{ml}$ TAS for $18 \mathrm{~h}$. Each cell lysate was subjected to an immunoblot analysis using the antibodies to PARP. Quantifications of PARP cleavage were performed by using KDS1 $\mathrm{d}^{\mathrm{TM}}$ image analysis.

order of the cleavage activity in this system was 4,15DAS $>$ TAS $>15-M A S>4-M A S$. Therefore, acetoxylation at $\mathrm{C}-15$ of the scirpenol structure increased the PARP cleavage activity in the Jurkat $T$ cell line.

Caspase Inhibitors Blocked the ASM-Induced PARP Cleavage As the involvement of caspase in the ASM-induced apoptosis in Jurkat T cells was observed, the presence of PARP cleavage in cells treated with Z-VAD-FMK, a pancaspase inhibitor and with Ac-DEVD-CHO, a caspase-3 inhibitor, was evaluated. Treatment with $10 \mu \mathrm{M}$ Z-VAD-FMK or $10 \mu \mathrm{M}$ Ac-DEVD-CHO alone did not affect PARP cleavage in the system. The pre-treatment of the Jurkat $\mathrm{T}$ cells with Ac-DEVD-CHO completely blocked the PARP cleavage induced by 4-MAS, and blocked the TAS-induced PARP cleavage by $35 \%$ (35\% PARP cleavage in the presence of AcDEVD-CHO vs. $66 \%$ cleavage in the absence of Ac-DEVDCHO). Ac-DEVD-CHO, however, failed to block the PARP cleavage induced by 15 -MAS $(44 \%$ vs. $51 \%)$ or 4,15 -DAS $(69 \%$ vs. $75 \%)$. The pre-treatment of the cells with Z-VADFMK significantly blocked the PARP cleavage induced by all the ASMs that were used in the current study (Fig. 5). These results indicate that 4-MAS- or TAS induced apoptosis by activating caspase-3, while 15-MAS or 4,15-DAS induced apoptosis by activating other caspases in the Jurkat T cells.

Induction of DNA Fragmentation by ASMs Apopto-
(A)

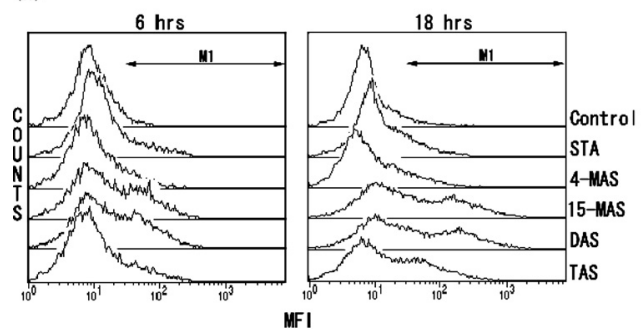

(B)

\begin{tabular}{|c|c|c|c|c|}
\hline \multirow{2}{*}{ Compound } & \multicolumn{2}{|c|}{$6 \mathrm{ehr}$} & \multicolumn{2}{|c|}{$18 \mathrm{hr}$} \\
\hline & $\%$ Gate & $\mathrm{MFI}^{*}$ & $\%$ Gate & $\mathrm{MFI}^{*}$ \\
\hline Control & 1.2 & 44.8 & 4.6 & 54.4 \\
\hline Staurosporine $(100 \mathrm{ng} / \mathrm{ml})$ & 12.4 & 78.4 & 16.4 & 62.2 \\
\hline $4-\operatorname{MAS}(100 \mathrm{ng} / \mathrm{ml})$ & 8.5 & $\mathbf{5 4 . 1}$ & 11.8 & 61.1 \\
\hline $15-\mathrm{MAS}(50 \mathrm{ng} / \mathrm{ml})$ & 28.1 & 71.2 & 46.0 & 176.8 \\
\hline $4,15-D A S(50 \mathrm{ng} / \mathrm{ml})$ & 31.6 & 72.1 & 47.7 & 200.6 \\
\hline TAS $(50 \mathrm{ng} / \mathrm{ml})$ & 12.9 & 70.3 & 30.7 & 89.3 \\
\hline
\end{tabular}

Fig. 6. Induction of DNA Fragmentation by ASMs Analyzed by Using FITC-dUTP Incorporation in Jurkat T Cells

(A) Histogram of FACS analysis, (B) values of percent gate and MFI at 6 and $18 \mathrm{~h}$ treatment with compounds. Jurkat T cells were treated with mycotoxins for 6 or $18 \mathrm{~h}$. Cells were first treated with $1 \%$ paraformaldehyde and then fixed in $70 \%$ ethanol. The fixed cells were stained with FITC-dUTP and propidium iodide and the incorporation of FITC-dUTP into the apoptotic cells was measured by flow cytometry. * MFI: mean fluorescent intensity.

sis-associated DNA fragmentation is induced by the DNA fragmentation factor, which is activated by caspases. dUTPs can be incorporated with the broken $3^{\prime}-\mathrm{OH}$ DNA ends catalyzed by TdT. Therefore, DNA fragmentation in apoptotic cells can be quantified using FITC-tagged dUTPs. When the Jurkat $\mathrm{T}$ cells were treated with ASMs, DNA fragmentation was observed after 6-h-incubation. A proportion of the DNA fragmented cells was increased in a time-dependent manner (Fig. 6). Among the ASMs that were tested, 4,15-DAS exhibited the most effective DNA fragmentation activity $(47.7 \%$ of the cells were DNA fragmented after 18-h incubation), while the proportion of DNA-fragmented cells treated with 4-MAS for $18 \mathrm{~h}$ accounted for $11.8 \%$. The order of the DNA fragmentation activity of the ASMs in the Jurkat T cells was 4,15-DAS $>15$-MAS $>$ TAS $>4$-MAS.

\section{DISCUSSION}

The insect-borne fungus Paecilomyces tenuipes is one of the most valued Chinese medicinal herbs. In a recent study that was conducted in Japan and China, entomopathogenic fungi such as Cordyceps were reported to have antitumor activity. ${ }^{28)}$ A strong cytotoxic compound, 4-MAS was isolated from the fruiting bodies of Paecilomyces tenuipes. ${ }^{16)}$ The backbone of 4-MAS is scirpenol. Its structural characteristics include $12-13$ epoxide groups and three hydroxyl groups at the positions 3, 4 and 15. 4-MAS is structurally related to sesquiterpenoid metabolites produced by fungi imperfecti such as the Fusarium, Cordyceps and Paecilomyces species. Oh et al. reported that 4-MAS isolated from Isaria japonica could induce apoptosis on human HL-60 leukemia cells. 
They showed DNA fragmentation and cell cycle arrest by treatment with the compound. ${ }^{15)} \mathrm{We}$, however, report herein the loss of mitochondrial inner membrane potential, externalization of inner phosphatidyl serine, PARP cleavage and DNA fragmentation by treatment with 4-MAS and its derivatives in Jurkat $\mathrm{T}$ cell line. In our system, the Jurkat $\mathrm{T}$ cell showed stronger apoptotic phenomena to ASM than other cell lines such as MOLT-4 and THP-1. ${ }^{21)}$ Also, 4-MAS was reported to have more distinctive cytotoxicity in HL-60 than other cell lines such as U-937, HeLa, MCF-7 and HepG2. ${ }^{15}$ )

Apoptosis is one of the most fundamental biological processes in eukaryotes, in which an individual cell dies through the activation of an intrinsic suicidal mechanism. The morphological and physiological events of the apoptotic process include PS externalization, the loss of mitochondriamembrane potential, the activation of caspases, PARP cleavage, nuclear DNA fragmentation, and cellular shrinkage, among others. In this study, the induction of apoptosis, not necrosis, by ASMs and the comparative cytotoxicities of these compounds depending on the positions and number of acetoxyl groups in the scirpenol moiety were reported. The ASM-treated cells exhibited typical apoptotic phenomena such as PS externalization, the loss of mitochondrial membrane potential, the acceleration of PARP cleavage, and the fragmentation of genomic DNA. The comparative cytotoxicity study revealed that among the ASMs, 4,15-DAS showed the most effective apoptotic activity in the Jurkat $\mathrm{T}$ cell line. Acetoxylation at $\mathrm{C}-15$ of the scirpenol family appeared to be essential for the manifestation of apoptotic activity in Jurkat $\mathrm{T}$ cells. When Jurkat $\mathrm{T}$ cells were treated with scirpenols acetoxylated at various positions, acetoxylation at C-3, 4, and 15 showed a strong cytotoxic effect, while single acetoxylation at $\mathrm{C}-4$ revealed a weak cytotoxic effect. The $\mathrm{IC}_{50}$ range of ASMs tested in the current study against human $\mathrm{T}$ lymphoid Jurkat cells was from 16.1 to $59.5 \mathrm{ng} / \mathrm{ml}$. In the annexin V assay, PS externalization by the ASMs that were tested was observed in the early phase of the incubation, which is one of the typical phenomena of apoptosis.

Staurosporine, an inhibitor of protein kinase C (PKC) and topoisomerase II, induces typical caspase-mediated apoptosis. ${ }^{9)}$ When Jurkat T cells were treated with ASMs for $12 \mathrm{~h}$, the loss of mitochondrial-membrane potential was observed. This could have been caused by an opening of the mitochondrial permeability transition pore and/or by channel-forming by the Bax. ${ }^{5)}$ It is therefore being considered that Jurkat $\mathrm{T}$ cells treated with ASMs may undergo mitochondria-mediated apoptosis. To investigate whether ASMs-induced apoptosis involves caspase activation and the subsequent cleavage of PARP, whole lysates of Jurkat T cells treated with ASMs were subjected to the immunoblot assay using the antibody specific to PARP. The results of this study indicate that ASMinduced PARP cleavage to an $89-\mathrm{kDa}$ fragment was blocked through the addition of caspase inhibitors such as Z-VADFMK and Ac-DEVD-CHO. The PARP cleavage induced by 4-MAS or TAS was markedly reduced in Jurkat $\mathrm{T}$ cells by the addition of Ac-DEVD-CHO, a caspase- 3 inhibitor, in the incubation medium, indicating caspase-3 was involved in the apoptosis induction through 4-MAS or TAS. On the other hand, 15-MAS- or 4,15-DAS-induced PARP cleavage was not affected by the addition of Ac-DEVD-CHO, suggesting apoptosis induction through 15-MAS- or 4,15-DAS was in- dependent of caspase-3 (Fig. 5). These data suggest that activation of caspases may be dependent on the number and position of acetoxylation of the ASMs. Further elucidation of the caspase involvement in apoptosis induction through ASMs needs to be clarified.

In the current study, Jurkat $\mathrm{T}$ cells were used as an apoptosis induction system to compare cytotoxicities caused by ASMs. As 4-MAS, monoacetoxylated at C-4 of scirpenol from the edible mushroom Paecilomyces tenuipes, had been successfully purified, the effect of the number and position of acetoxyl groups in the moiety of scirpenol on cytotoxicity, especially on apoptosis, was explored. Taken together, the results of these studies clearly indicate that the cytotoxic activity of 4-MAS and its derivatives in the Jurkat $\mathrm{T}$ cell can be attributed to apoptosis. Furthermore, the information regarding the structure-activity relationship of the ASM family gathered from this study may prove to be useful in the research that is being conducted on comparative cytotoxicity and on the intoxication of acetoxyscirpenol or the trichothecene mycotoxin family. Further studies, such as immunoblot assays for cytochrome $c$ release and translocation of Bax, must be conducted to determine whether ASM-induced apoptosis goes through a mitochondria-mediated apoptotic pathway.

Acknowledgements This study was supported by a grant (\#2004-80, HW Kim) of The University of Seoul, Korea, and the 2003 High Tech Facility Grant (HW Kim) from The University of Seoul. The authors appreciate these supports.

\section{REFERENCES}

1) Ormerod M. G., J. Immunol. Methods, 265, 73-80 (2002).

2) Tidd D. M., Spiller D. G., Broughton C. M., Norbury L. C., Clark R. E., Giles R. V., Nucleic Acids Res., 28, 2242-2250 (2000).

3) Fulda S., Scaffidi C., Susin S. A., Krammer P. H., Kroemer G., Peter M. E., Debatin K. M., J. Biol. Chem., 273, 33942-33948 (1998).

4) Li M., Kondo T., Zhao Q., Li F., Tanabe K., Arai Y., Zhou Z., Kasuya M., J. Biol. Chem., 275, 39702-39709 (2000).

5) Finucane D. M., Bossy-Wetzel E., Waterhouse N. J., Cotter T. G., Green D. R., J. Biol. Chem., 274, 2225-2233 (1999).

6) Alvarez-Gonzalez R., Spring H., Müller M., Bürkle A., J. Biol. Chem., 274, 32122-32126 (1999).

7) Bernstein C., Bernstein H., Payne C. M., Garewal H., Mutation Res., 511, 145-178 (2002).

8) Widlak P., Acta Biochimica. Polonica., 47, 1037-1044 (2000).

9) Lassota P., Singh G., Kramer R., J. Biol. Chem., 271, 26418-26423 (1996).

10) Sweeney M. J., Dobson A. D., FEMS Microbiol. Lett., 175, 149-163 (1999).

11) Desjardins A. E., Hohn T. M., McCormick S. P., Microbiol. Rev., 57, 595-604 (1993)

12) Wang J. S., Busby W. F., Jr., Wogan G. N., Toxicol. Appl. Pharmacol., 140, 264-273 (1996).

13) Bukowski R., Vaughn C., Bottomley R., Chen T., Cancer Treat. Rep., 66, 381-383 (1982).

14) Shifrin V. I., Anderson P., J. Biol. Chem., 274, 13985-13992 (1999).

15) Oh G. S., Hong K. H., Oh H., Pae H. O., Kim I. K., Kim N. Y., Kwon T. O., Shin M. K., Chung H. T., Biol. Pharm. Bull., 24, 785-789 (2001).

16) Nam K. S., Jo Y. S., Kim Y. H., Hyun J. W., Kim H. W., Life Sci., 69, 229-237 (2001)

17) Fukatsu T., Sato H., Kuriyama H., J. Invertebr. Pathol., 70, 203-208 (1997).

18) Chung E. J., Choi K., Kim H. W., Lee D. H., Biol. Pharm. Bull., 26, $32-36$ (2003). 
19) Lee D. H., Kim H. W., J. Appl. Pharmacol., 12, 74-78 (2004).

20) Park I. W., Hwang G. S., Kim H. W., Lee D. H., J. Appl. Pharmacol., 12, 250-256 (2004).

21) Han H. C., Lindequist U., Hyun J. W., Kim Y. H., An H. S., Lee D. H., Kim H. W., Pharmazie, 59, $42-49$ (2004).

22) Richardson K. E., Hamilton P. B., Poult. Sci., 69, 397-402 (1990).

23) Vermes I., Haanen C., Steffens-Nakken H., Reutelingsperger C., J. Immunol. Meth., 184, 39-51 (1995).

24) Singh N. P., Exp. Cell Res., 256, 328-337 (2000).
25) Leoni L. M., Chao Q., Cottam H. B., Genini D., Rosenbach M., Carrera C. J., Budihardjo I., Wang X., Carson D. A., Proc. Natl. Acad. Sci., 95, 9567-9571 (1998).

26) Johnson B. W., Boise L. H., J. Biol. Chem., 274, 18552-18558 (1999).

27) Li X., Traganos F., Melamed M. R., Darzynkiewicz Z., Cytometry, 20, $172-180(1995)$.

28) Yoshida J., Takamura S., Yamaguchi N., Ren L. J., Chen H., Koshimura S., Suzuki S., Jpn. J. Exp. Med., 59, 157-161 (1989). 